\title{
Natural Recovery and Planned Intervention in Coastal Wetlands: Venice Lagoon (Northern Adriatic Sea, Italy) as a Case Study
}

\author{
Chiara Facca, Sonia Ceoldo, Nicola Pellegrino, and Adriano Sfriso \\ Department of Environmental Sciences, Informatics \& Statistics, Ca' Foscari University of Venice, \\ Calle Larga Santa Marta 2137, 30123 Venice, Italy \\ Correspondence should be addressed to Chiara Facca; facca@unive.it
}

Received 7 March 2014; Revised 5 June 2014; Accepted 6 June 2014; Published 13 July 2014

Academic Editor: Maria Alexandra Teodósio

Copyright (C) 2014 Chiara Facca et al. This is an open access article distributed under the Creative Commons Attribution License, which permits unrestricted use, distribution, and reproduction in any medium, provided the original work is properly cited.

The goals of conservation and sustainable use of environmental ecosystems have increased the need for detailed knowledge of ecological evolution and responses to both anthropogenic pressures and recovery measures. The present study shows the effects of natural processes and planned intervention in terms of reducing nutrient inputs in a highly exploited coastal lagoon, describing its evolution over a 16-year period from the late 1980s (when eutrophication was at its peak) until 2003. Changes in nutrient and carbon concentrations in the top layer of sediments were investigated in parallel with macroalgal and seagrass biomass in the most anthropized basin of Venice Lagoon in four surveys conducted in accordance with the same protocols in 1987, 1993, 1998, and 2003. A pronounced reduction in trophic state (mainly total nitrogen, organic phosphorus, and organic carbon concentrations) and macroalgal biomass was recorded, together with the progressive expansion of seagrass meadows. General considerations are also made on the effects of Manila clam farming and the shift from illegal to managed clam farming.

\section{Introduction}

Since the mid-20th century, in addition to land reclamation, coastal areas have been seriously affected by eutrophication, compromising environmental equilibria and species diversity. The accentuation of these problems has been studied and described from many points of view, considering human activities, hydrodynamic and morphological features of basins, and so forth [1-3]. Partly because ecosystems have been shown to vary widely in terms of their sensitivity to nutrient enrichment [2], it may be difficult to distinguish between natural nutrient concentrations and anthropogenic inputs. However, the loss of seagrass beds appears to be a common pattern in coastal areas affected by eutrophication [4-6]. Although little historical information is available on seagrass distribution, a general decline in coverage has been reported for most European coastal waters and less than 15\% of shorelines can be considered to be in good condition [7]. On a global scale, seagrass loss due to anthropic activities is estimated at $60 \%$ [5].

Since 1971, when the Ramsar convention [8] was signed, a number of protection policies have been adopted at the European level for reducing the effects of anthropogenic disturbances and for the conservation and recovery of marine and coastal natural heritage (see Table 1 in [7]). The latest EU regulations are set out in the Water Framework Directive (WFD 2000/60/EC) and the Marine Strategy Directive (2008/56/EC), which establish common objectives for member states in the assessment and recovery of aquatic ecosystems. In 1998, a Spanish National Ramsar Report estimated that $56.6 \%$ of coastal wetlands had been lost, and restoration processes were planned by regional authorities in deeply degraded ecosystems, such as the brackish lagoon of Senillar de Moraira (Mediterranean Valencia Region, Spain [9]). In this case the intervention plan mainly consisted of rebuilding the hydrogeomorphological features but the remaining anthropogenic pressures (dense urban and recreational areas) strongly compromised the restoration processes and the ecosystem functioning did not appear selfsustainable, requiring continuous maintenance measures [9]. The need to combine restoration with the removal of the causes of degradation in order to favour the self-maintenance of natural processes is a major challenge [9]. Similar but more encouraging results were observed in Veerse Meer coastal lagoon (Netherlands, North Sea), where the measures consisted of opening up a connection between the enclosed 


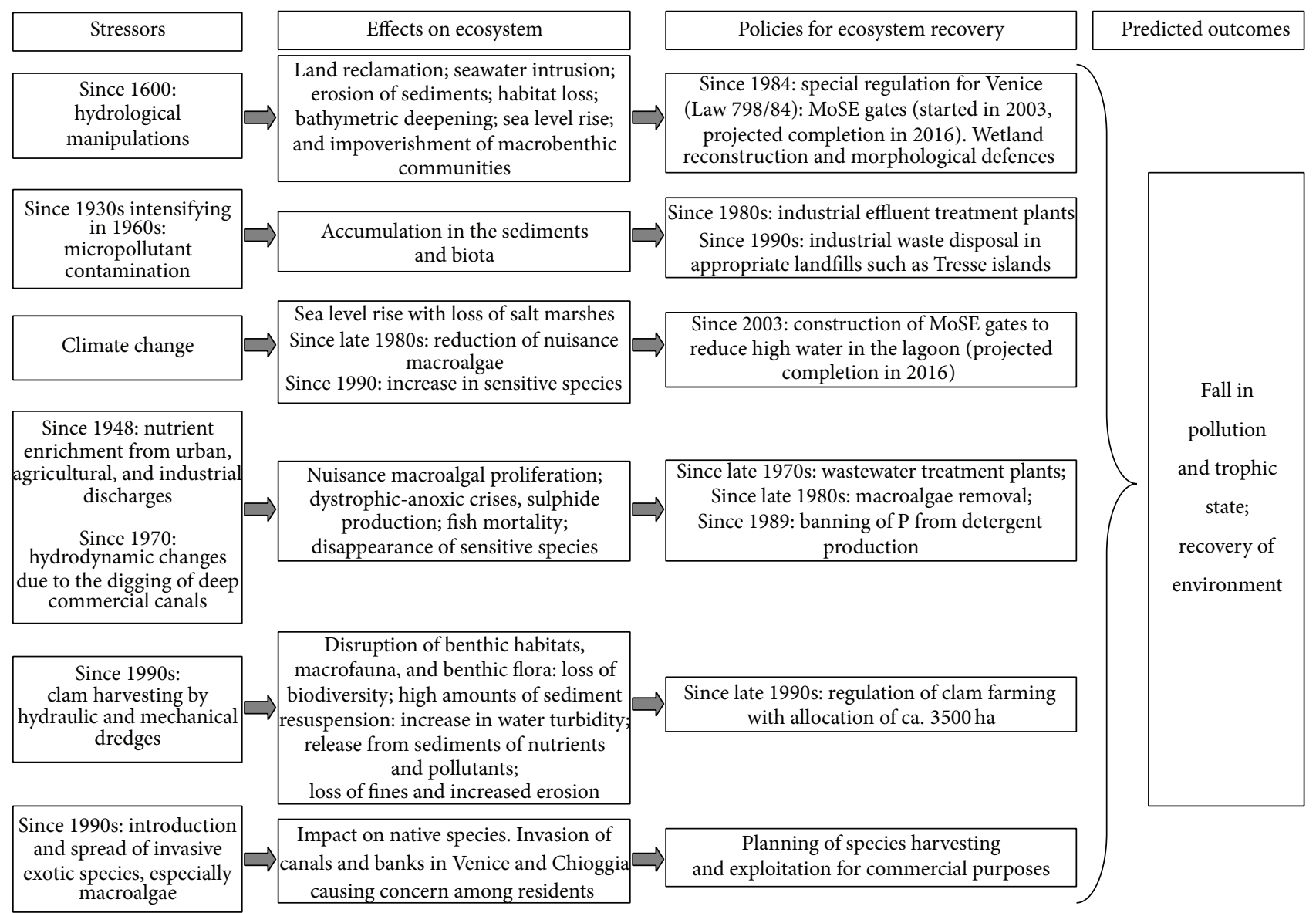

FIGURE 1: Scheme of main stressors (categories in accordance with [4]) affecting Venice Lagoon, effects on ecosystem, policies adopted, and predicted outcomes.

brackish lagoon and the adjacent marine bay [10]. Rapid and constant improvement of water quality was seen, with reductions in nutrient concentrations and frequency of algal blooms and an increase in water transparency. Nevertheless, corresponding positive effects were not observed for the composition and abundance of macrofauna, which may have been affected by changes in hydrodynamism and consequent sediment resuspension [10]. As with Senillar de Moraira, in this latter case the restoration consisted of modifying the hydrological features with no direct measures to reduce nutrient inputs, which remain a major threat to aquatic ecosystem functioning. Better results were observed in Tampa Bay (Florida, USA), where cyanobacteria blooms became less frequent and seagrasses recolonized the bay following a 10fold reduction in annual wastewater $\mathrm{N}$ loading [4].

Assessing recovery measures may be complicated by the need for a good understanding of interactions between stressors and by the different sensitivity of coastal ecosystems to anthropogenic pressures. However, most of the conceptual models describing eutrophication processes associate the presence of well-developed seagrass beds with pristine conditions $[5,6,11]$ and they are recognized as indicators of good/high ecological quality (sensu Water Framework Directive [12]). Hence, the presence/absence of angiosperms can represent a starting point for verifying the efficiency of coastal management and gaining a better understanding of the complexity of transitional ecosystems.

On the basis of the conceptual model described in [4], we identified the stressors affecting Venice Lagoon (Northern Adriatic Sea, Italy) and the main effects on the ecosystem with reference to the available literature [13]. Figure 1 highlights the multiplicity of human pressures affecting this particular basin. For each stressor, the environmental consequences and resulting policies are cited. The management of Venice Lagoon is of international concern due to the historical heritage of the city, increasingly threatened by flood damage. Considerable sums have thus been invested in the MoSE gates (experimental electromechanical module), which will close off the inlets connecting the lagoon to the sea at times of "Acqua Alta" (high tide) thereby reducing the environmental impact and erosion (http://www.salve.it/uk/soluzioni/acque/ f_avanzamento.htm; last access November 15, 2013).

In the early 1970s industrial inputs of nitrogen and phosphorus to the lagoon were estimated to be $8200-10060$ and 1100-1900 tonnes $\mathrm{y}^{-1}$, respectively [14]. These nutrient loads favoured the proliferation of nuisance macroalgae, which in the central lagoon basin produced one of the highest standing crops in the world (between 5 and $20 \mathrm{~kg}$ fwt $\mathrm{m}^{-2}$ over a surface area of $66 \mathrm{~km}^{2}$ [15]). Our first survey in the central part 
of the lagoon in 1987 was carried out under such conditions, when seagrass beds had already disappeared. By the end of the 1990s, industrial inputs of nutrients had decreased by about one order of magnitude [16], thanks to the positive effects of waste water treatment plants and progressively falling industrial production. However, the disappearance of nuisance macroalgal blooms in the early 1990s depended on a combination of several factors, including unfavorable weather conditions, increasing water turbidity, and grazing pressure [15, $17,18]$. The complete absence for many years of dystrophicanoxic crises and the strong reduction of macroalgae on the bottom favoured the spread of the Manila clam Tapes philippinarum Adams \& Reeve (introduced into the lagoon in 1983 for aquaculture purposes), reaching biomass of up to $7.45 \mathrm{~kg}$ $\mathrm{m}^{-2}$ [19]. In a few years the high clam biomass became an important economic resource, with production peaking at ca. 40,000 tonnes in 1998 (the year of our third survey), mainly harvested by unauthorized fishermen [20]. The continuous resuspension of sediments caused by harvesting techniques strongly affected the benthic habitat, reducing light transmission and altering sediment compactness and texture [21,22] as well as oxygenation [23]. A further result of sediment resuspension was that nutrient [24] and pollutant $[25,26]$ concentrations decreased. Due to the dramatic impact on the lagoon ecosystem and the risks for human health (clams were illegally harvested in polluted areas), clam farming was regulated by restricting it to specific areas (Figure 2). About 3500 ha were assigned by the local administration [20], reducing the impact of this activity on surface sediments and favouring their recolonization by seagrasses.

This paper aims to describe

(i) trophic conditions throughout the lagoon before the start of work on the MoSE project in 2003, thereby providing a benchmark against which future changes in ecological features can be assessed,

(ii) ecological evolution over a 16-year period, moving from the peak eutrophication of the late 1980s, through the period of uncontrolled clam harvesting activities, until the attempts at sustainable clam farming.

\section{Materials and Methods}

2.1. Study Area Characteristics. Venice Lagoon (Figure 2) is located in the Northwestern Adriatic Sea. It has a surface area of ca. $550 \mathrm{~km}^{2}$ of which ca. 432 are subject to tidal exchange. During each tidal cycle $(12 \mathrm{hr}) \mathrm{ca} .60 \%$ of the lagoon's waters are exchanged with the sea through three large inlets (400$900 \mathrm{~m}$ wide and 8-20 $\mathrm{m}$ deep). Except for the main channels, the mean water depth is approximately $1 \mathrm{~m}$. The mean tidal amplitude is ca. $60 \mathrm{~cm}$ [28], but during syzygy tides it ranges between 1 and $1.5 \mathrm{~m}$. The lagoon receives industrial and treated urban wastewaters from a large drainage network $\left(1839 \mathrm{~km}^{2}[14]\right)$, as well as untreated urban sewage from the historical city of Venice, the islands of Lido and Pellestrina, and the city of Chioggia and its hinterland (ca. 300,000 inhabitants).

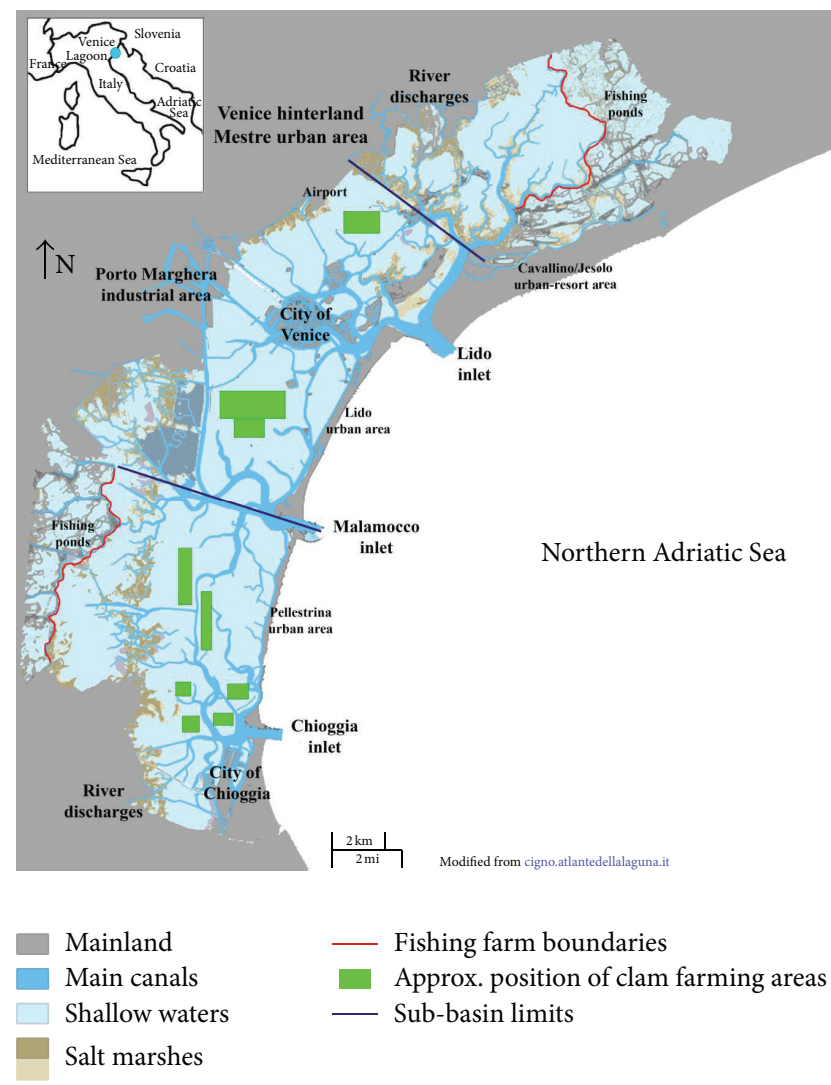

FIGURE 2: Study area: Venice Lagoon. Main anthropogenic pressures indicated in bold black. Solid blue lines separate lagoon into three morphological basins. Details of clam farming areas in [27].

With reference to morphological features the lagoon is divided into three basins (Figure 2):

(i) the northern basin, delimited to the south by the Burano and Torcello salt marshes, which has few inhabited areas, little naval traffic, and low hydrodynamism;

(ii) the central basin, bounded to the north by the Burano and Torcello salt marshes and to the South by the Malamocco-Marghera Ship Canal. This basin is characterised by the highest anthropogenic pressures due to urban, industrial, and maritime activities;

(iii) the southern basin to the south of the MalamoccoMarghera Ship Canal, where human pressures are relatively low and mainly related to clam farming. This is the largest of the three basins.

2.2. Sampling and Analytical Methods. In the last week of June and the first few days of July 2003, sampling was conducted throughout the lagoon. A total of 165 sites were sampled, including the 31 of previous surveys (June 1987, June 1993, and June 1998). The site locations are displayed in Figures 3, 4,5 , and 6 . They are located exclusively in areas of the lagoon that are subject to tidal exchange; enclosed fishfarming ponds were not considered as they are managed as private properties and regulated in accordance with the needs of fish-farming. Indeed, they are not included in ecological 


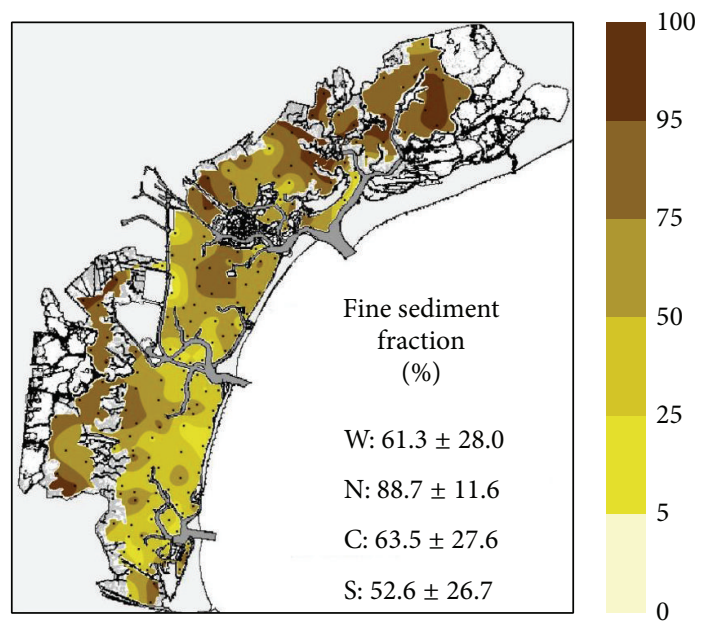

(a)

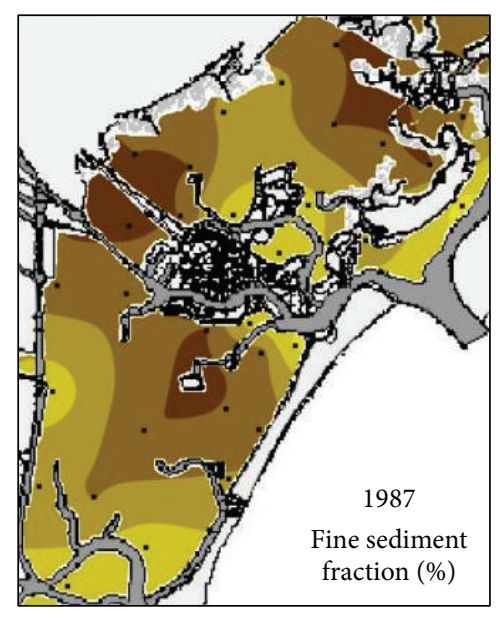

(b)

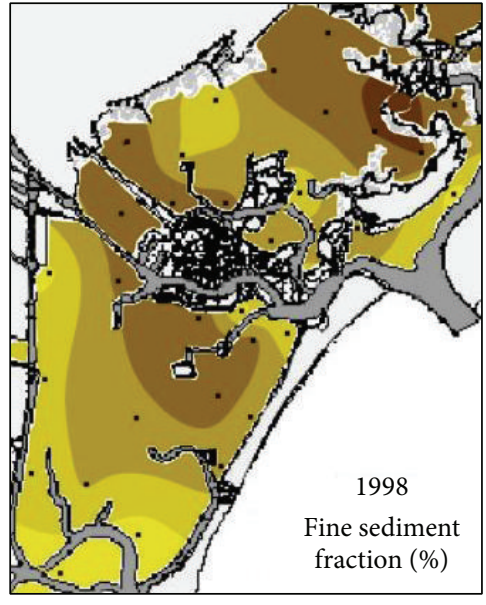

(c)

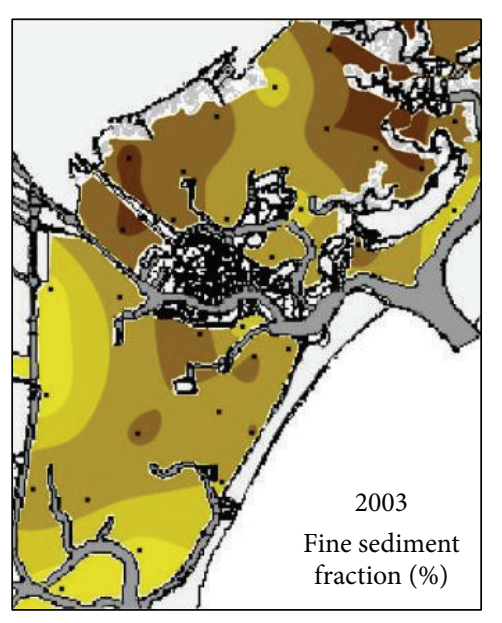

(d)

Figure 3: Spatial distribution of fine sediments (fraction $<63 \mu \mathrm{m}$ ) in 2003 (a). Mean values and standard deviations shown on map for whole lagoon (W) and northern (N), central (C) and southern (S) basins. Other maps indicate distributions in 1987 (b), 1998 (c), and 2003 (d) in central basin.

restoration policies because it is recognized that the benefits of such uses need to be retained (sensu WFD).

In order to obtain comparable results, the sampling procedures and analytical protocols were the same as those of the previous 3 surveys (1987, 1993, and 1998).

Sediment samples of the top $5 \mathrm{~cm}$ layer were obtained by mixing 3-4 cores collected by a Plexiglas corer (i.d. $10 \mathrm{~cm}$ ). The sites selected for our investigations are representative of the study areas and are characterized by uniform sediment texture. They are distant from channel edges or bottom discontinuities, and therefore intrasite variability is low and the mixing of 3-4 cores guarantees variability of less than $5 \%$.

The water parameters near the bottom were

(i) temperature $(T)$ and $\mathrm{pH}$, measured by portable $\mathrm{pH}$ meter (model HD 8705, Delta OHM, Padua, Italy) equipped with a thermocouple (precision $0.1^{\circ} \mathrm{C}$ );

(ii) chlorinity, determined argentometrically in the laboratory using a modified version of the Knudsen method [29]. Salinity $(S)$ was calculated in accordance with the formula $\mathrm{Cl}^{-} \times 1.805+0.03$; (iii) dissolved oxygen, measured by portable oximeter (Oxi 196, Wissenschaftlich-Technische Werkstätten $\mathrm{GmbH}$, Weilheim, Germany). The data are reported as the oxygen saturation percentage (OS), taking account of water temperature and salinity;

(iv) light extinction depth, measured by Secchi disk (SD).

In the top $5 \mathrm{~cm}$ sediment layer the parameters were

(i) mud content: the fine sediment fraction, that is, $<63 \mu \mathrm{m}$ (fines), was determined by wet sieving [30] in order to classify the lagoon sediments in accordance with [31] into 6 textural classes: $<5 \%$ sand; $5-25 \%$ slightly muddy sand; $25-50 \%$ muddy sand; $50-75 \%$ sandy mud; $75-95 \%$ slightly sandy mud; and $>95 \%$ mud;

(ii) the amount of dry sediment by unit of volume (dry density: gdwt $\mathrm{cm}^{-3}$ ). Sediment dry density (SDD) was used to normalise nutrient concentration by volume; 


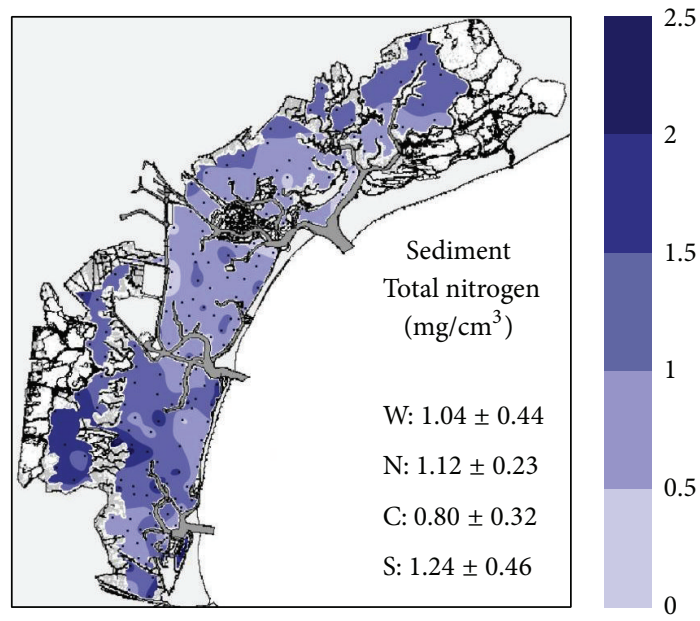

(a)

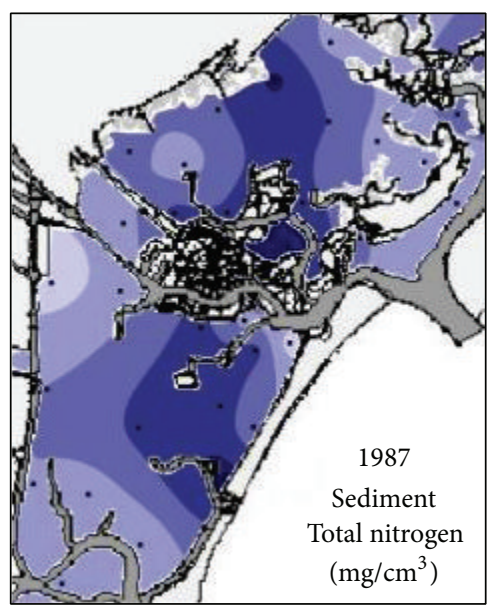

(b)

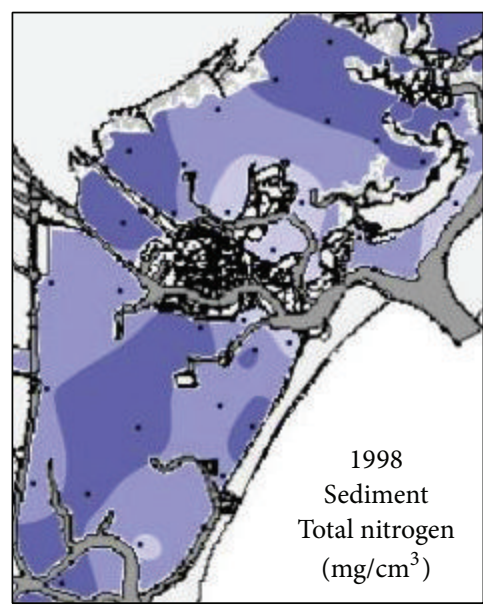

(d)

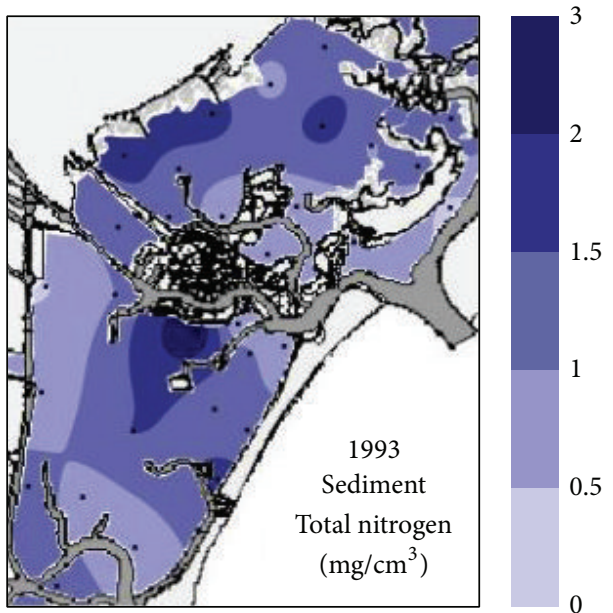

(c)

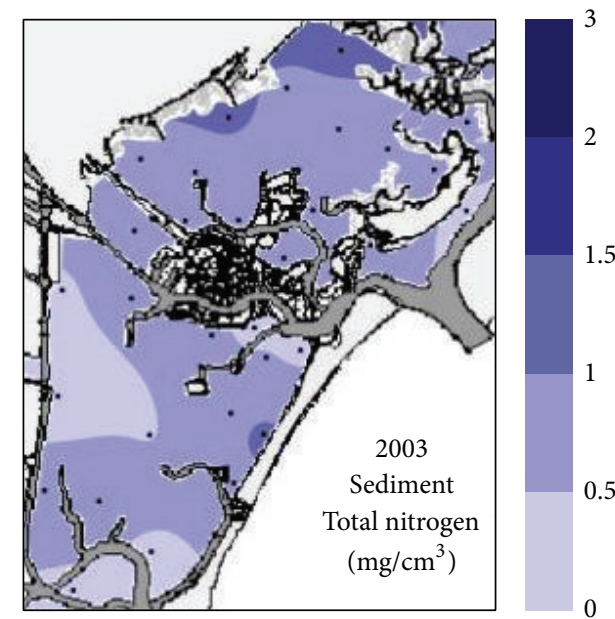

(e)

FIGURE 4: Spatial distribution of TN in 2003 (a). Mean values and standard deviations shown on maps for whole lagoon (W) and northern $(\mathrm{N})$, central (C) and southern (S) basins. Other maps indicate distributions in 1987 (b), 1993 (c), 1998 (d), and 2003 (e) in central basin. 


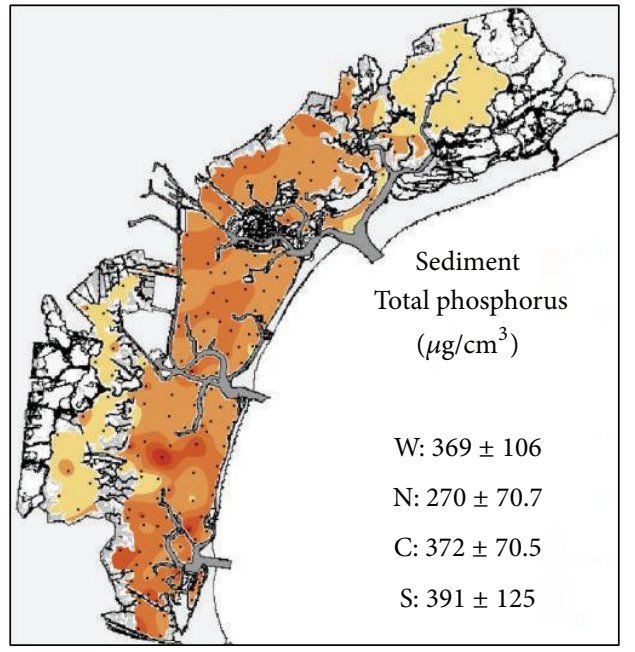

(a)

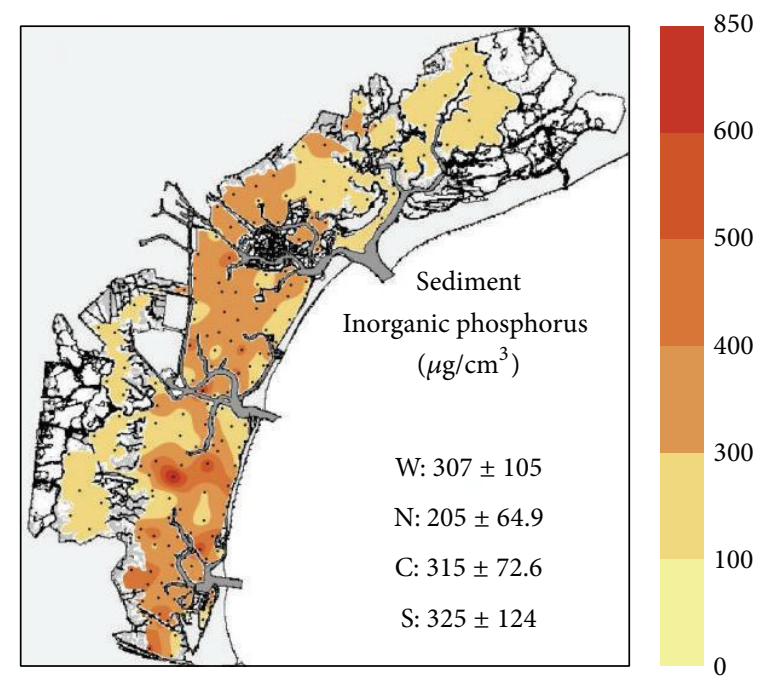

(b)

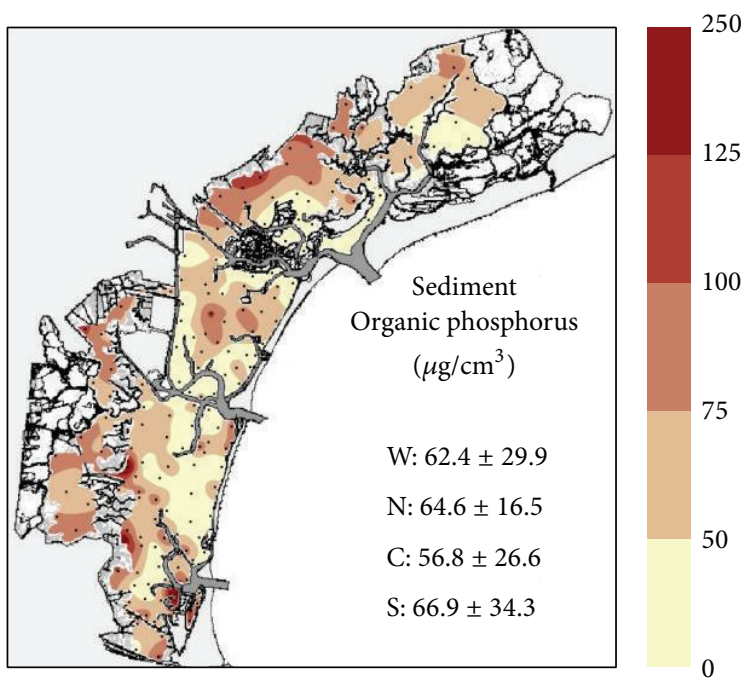

(c)

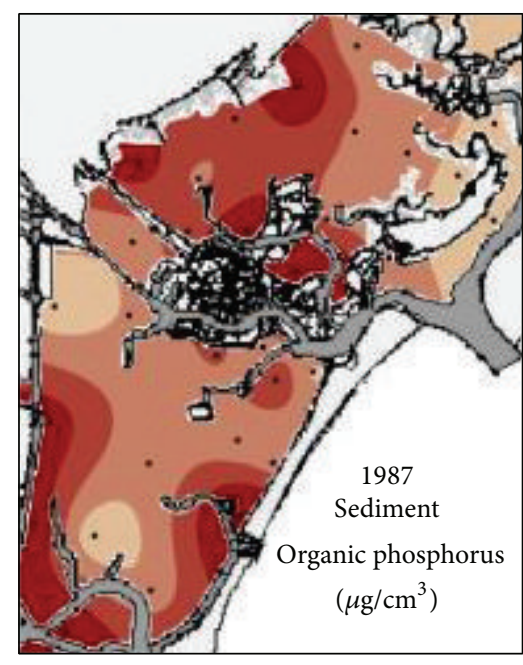

(d)

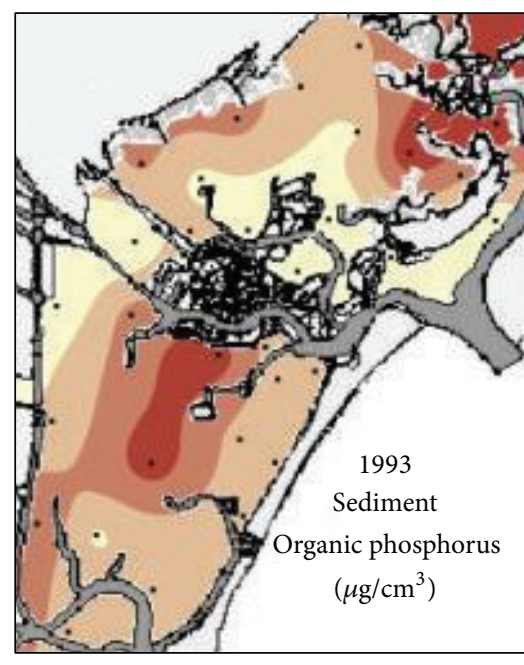

(e)

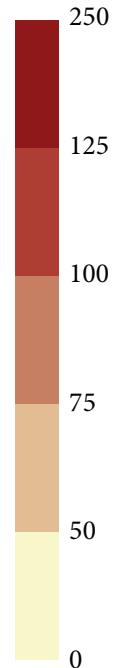

Figure 5: Continued. 


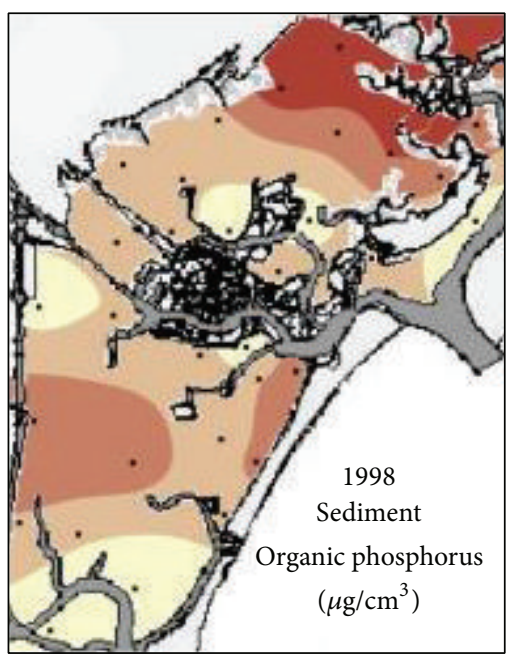

(f)
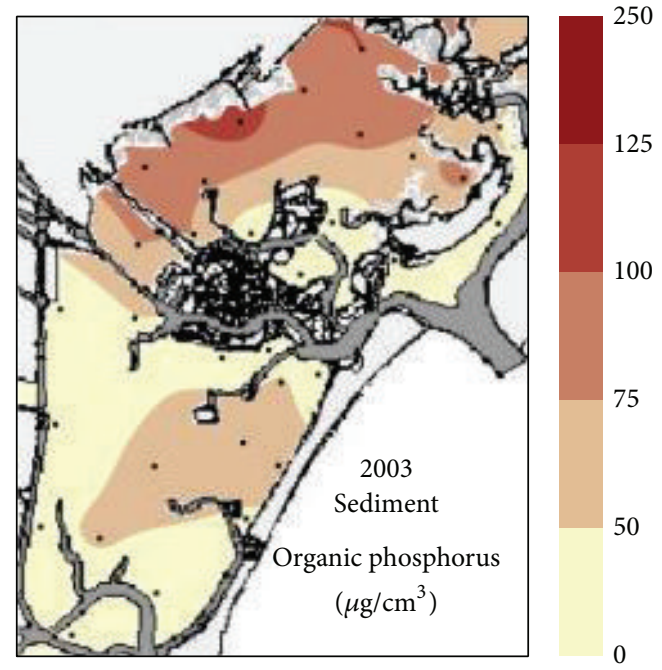

(g)

FIGURE 5: Spatial distribution of phosphorus concentrations in 2003: total phosphorus (a), inorganic phosphorus (b), and organic phosphorus (c). Mean values and standard deviations shown on maps for whole lagoon (W) and northern (N), central (C) and southern (S) basins. Other maps indicate distributions in 1987 (d), 1993 (e), 1998 (f), and 2003 (g) in central basin.

(iii) inorganic phosphorus (IP), measured by sediment sonication in $1 \mathrm{~N} \mathrm{HCl}$ of finely pulverized freeze-dried samples (ca. $0.4 \mathrm{~g}$ ) in accordance with Aspila et al. [32]. The resulting solutions were analyzed spectrophotometrically in accordance with Strickland and Parsons [33]. TP was obtained using the same procedure after $2 \mathrm{hrs}$ combustion at $550^{\circ} \mathrm{C}$ and the $\mathrm{OP}$ fraction was calculated from the difference. All measurements were replicated until the experimental error was $<5 \%$;

(iv) TN, TC, and IC concentrations, measured by Carlo Erba CNS Autoanalyser, mod. NA 1500. TN and TC were analyzed directly after sediment powdering and IC was determined by combusting samples for $2 \mathrm{hrs}$ at $440^{\circ} \mathrm{C}$ in order to eliminate most of the organic matter with negligible loss of carbonates [34]. For mainly carbonatic sediments $(50-80 \%)$ as in the current case, this temperature has been found to yield the closest results to those obtained with the acidification method described by Froelich [35]. Both methods are susceptible to systematic errors arising from the elimination of OC and IC, but the combustion method is preferable because the acidified samples may destroy some of the components of the CNS-analyzer. OC was determined from the difference. All analyses were replicated on different days till the experimental error was $<5 \%$.

The concentrations of nutrients in the top layer of sediments were normalised with reference to dry sediment density in order to obtain actual nutrient loads per unit of volume $\left(\mathrm{cm}^{3}\right)$. The raw concentrations expressed per unit of weight (g) reflect the substance inputs, whereas the normalized values highlight how they are distributed in the environment in relation to sediment characteristics [24].
The results were mapped using the Surfer system (Golden Software Inc., 1993-2000), applying the kriging method.

In accordance with the previous sampling protocols [18] and literature data on the annual growth of each species [3638], macroalgae were recorded within 6 biomass ranges: $0.01-$

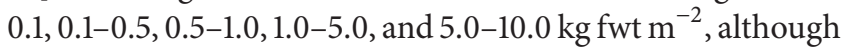
in the southern lagoon the highest range was only 1.0$2.0 \mathrm{~kg}$ fw t $\mathrm{m}^{-2}$. The three seagrass species (Cymodocea nodosa (Ucria) Asherson, Zostera marina Linnaeus, and Nanozostera noltii (Hornemann) Tomlinson et Posluzny) were sampled separately, with biomass (shoots + roots and rhizomes) recorded within four coverage ranges: $0-25 \%, 25-50 \%, 50-$ $75 \%$, and $75-100 \%$, corresponding to the following biomass

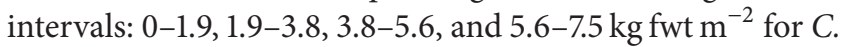
nodosa, $0-1.5,1.5-3.0,3.0-4.5$, and $4.5-6.3 \mathrm{~kg} \mathrm{fwt} \mathrm{m}^{-2}$ for $Z$.

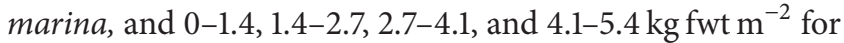
N. noltii.

2.3. Statistical Analyses. Before any statistical analysis, the distribution of each variable was tested for normality by the Kolmogorov-Smirnov test $(p<0.05)$, variables with nonparametric distribution being pre-treated by log-transformation. All variables were then standardized (mean 0 and variance 1 ) in order to reduce the variability arising from the different units of measurement

Non-parametric Spearman's correlation coefficients $\left(r_{s}\right)$ were considered significant at a $p$ value of $<0.001$, data being processed using STATISTICA 7.1 (StatSoft srl). Redundancy analysis (RDA) was carried out on a matrix of 165 cases (sites) and 11 independent variables (salinity, $\mathrm{pH}$, dissolved oxygen, mud content, inorganic and organic carbon, inorganic and organic phosphorus, total nitrogen, and macroalgal and seagrass biomass) to determine the part of the variation in species composition explained by environmental variables, data being processed using CANOCO 5 . 


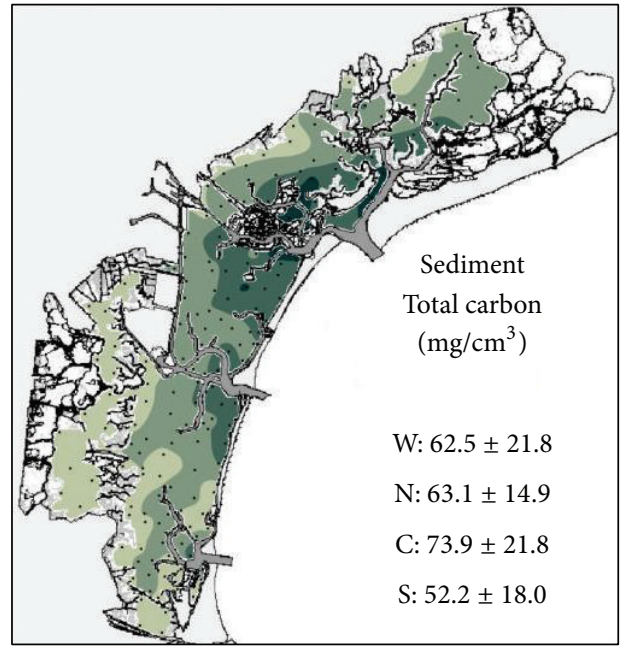

(a)

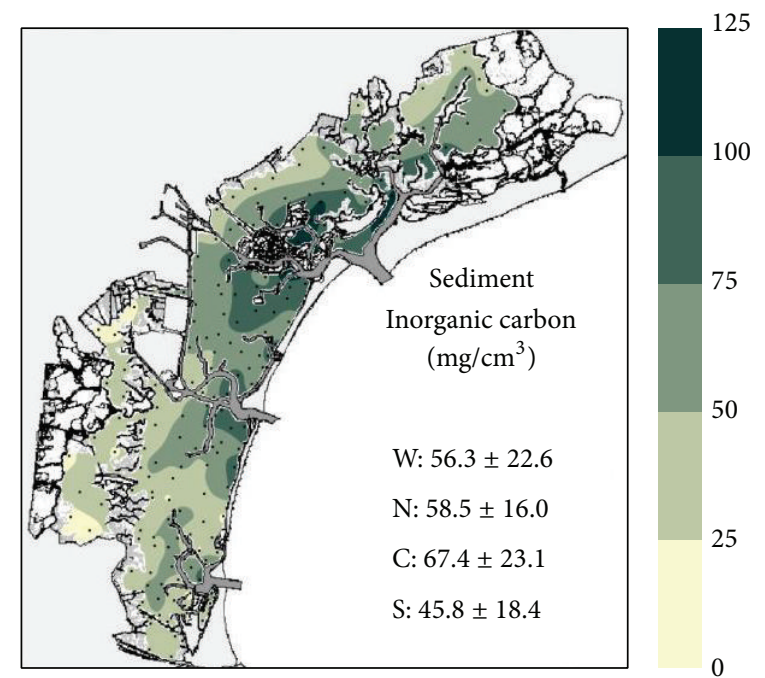

(b)

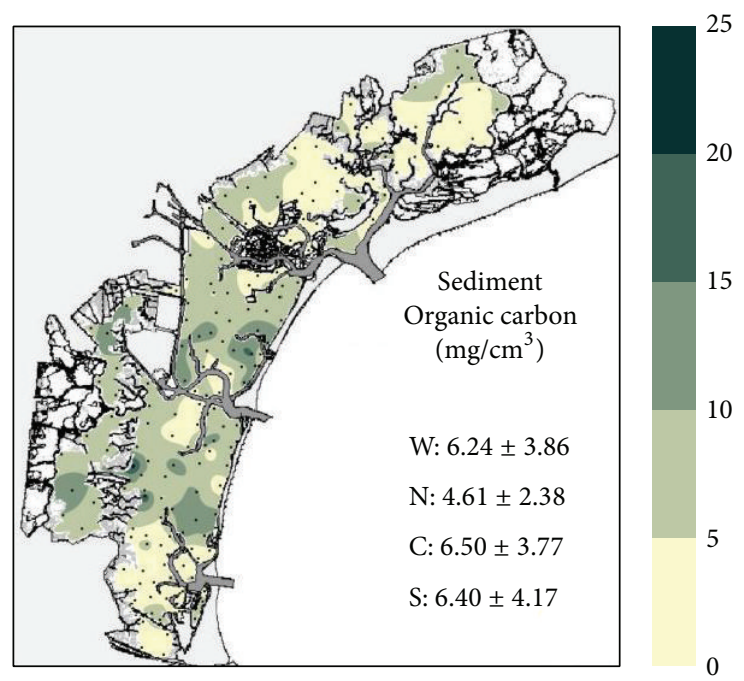

(c)

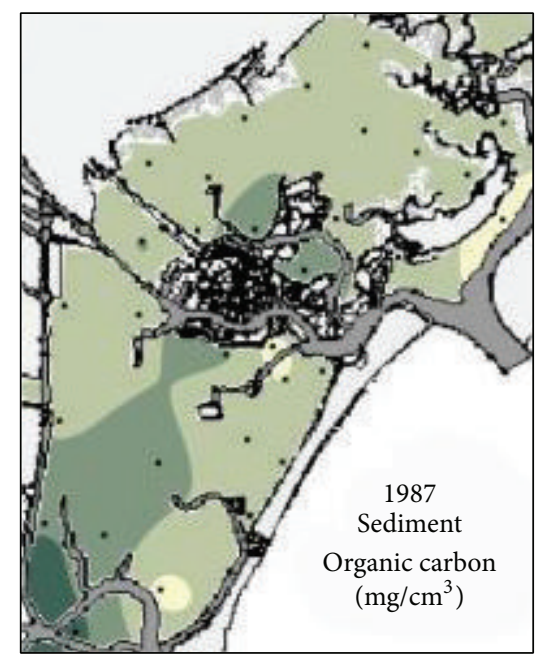

(d)

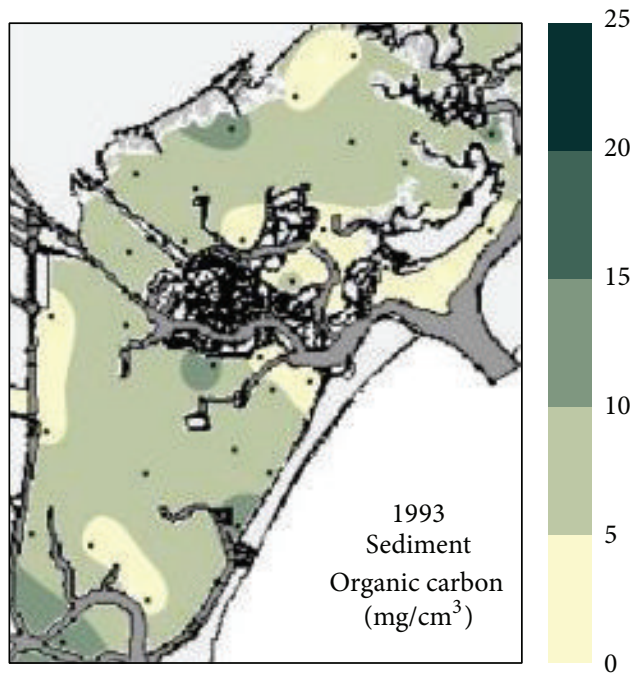

(e)

Figure 6: Continued. 


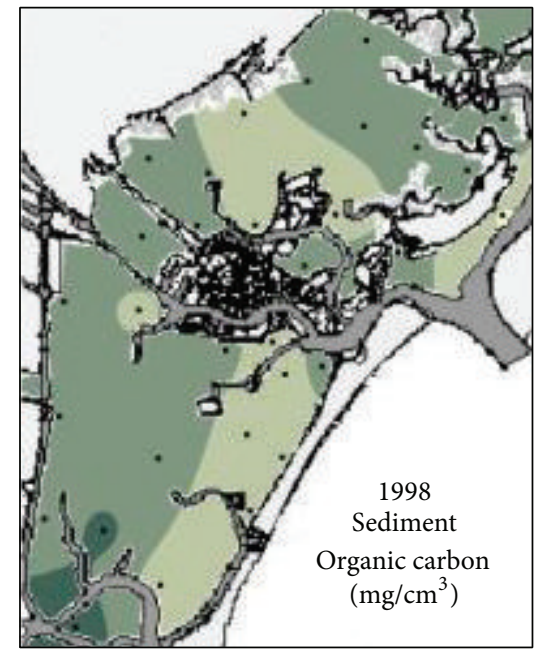

(f)

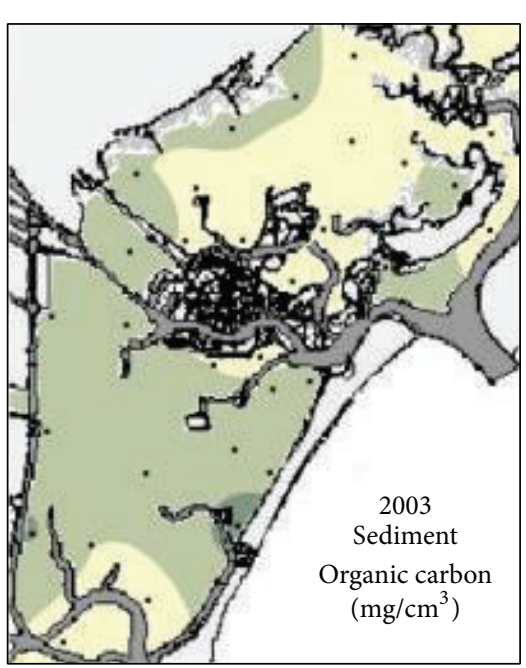

(g)

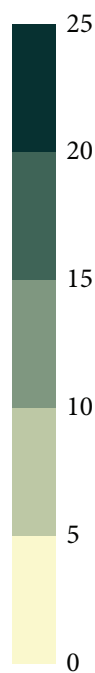

0

FIgURE 6: Spatial distribution of carbon concentrations in 2003. Total carbon (a), inorganic carbon (b), and organic carbon (c). Mean values and standard deviations shown on maps for whole lagoon $(\mathrm{W})$ and northern $(\mathrm{N})$, central $(\mathrm{C})$ and southern $(\mathrm{S})$ basins. Other maps indicate distributions in 1987 (d), 1993 (e), 1998 (f), and 2003 (g) in central basin.

To verify changes occurring between the surveys carried out in 1987, 1993, 1998, and 2003 in the central lagoon, 31 sites were compared by two-way ANOVA ( $p$ value $<0.05$ ). The data were considered to be comparable, as the sampling position and protocols, as well as the laboratory analytical procedures, were exactly the same.

\section{Results}

\subsection{Findings for the Whole Lagoon (2003)}

3.1.1. Physico-Chemical Parameters. The descriptive statistics for the main physico-chemical parameters are reported in Table 1. The central basin showed lower salinity and $\mathrm{pH}$ than the others. It also had the worst underwater light transmission, on the landward side.

The lagoon is characterised by sandy mud (Table 1; Figure 3(a)) except for the northern basin, where slightly sandy mud prevails (Figure 3(a)). It is important to note that areas of sand or slightly muddy sand were not only located on the seaward side of the lagoon, where they naturally occur in transitional systems, but also close to the industrial area, into which a river once flowed, being diverted in the 15th century (Figure 3(a)).

3.1.2. Nutrient Concentrations. The concentration distributions of total nitrogen (TN), total, inorganic, and organic phosphorus (TP, IP, OP), and total, inorganic, and organic carbon (TC, IC, OC) are shown in Figures 4, 5, and 6, together with means and standard deviations for each parameter.

The northern and southern basins displayed a clear TN gradient, with values descending from landward to seaward, whereas a more homogeneous distribution was observed in the central one (Figure 4(a)). TP distribution differed from that of $\mathrm{TN}$, the highest concentrations being recorded in the central basin (Figure 5(a)). Although OP had patchy distribution, a decreasing seaward gradient was observed almost throughout the lagoon (Figure 5(c)). OP accounted for between 0.9 and $59.5 \%$ of TP and was $18 \%$ on average.

TC and IC concentrations were highest in the central basin around the city of Venice, decreasing towards the other basins and towards the landward side (Figures 6(a) and 6(b)). The sites closest to the three seaward inlets, above all in the Lido inlet, showed high IC concentrations due to the dominance of dolomite (and to a lesser extent calcite) of fluvial origin [39]. In contrast, the lowest concentrations $\left(<25 \mathrm{mg} \mathrm{cm}^{-3}\right.$, Figure 6(b)) were recorded in the confined sites of the southern basin. OC was $<5 \mathrm{mg} \mathrm{cm}^{-3}$ in most of the lagoon, exceeding $5 \mathrm{mg} \mathrm{cm}^{-3}$ only in the sites north of Venice, close to Chioggia and in the salt marshes of the southern basin (Figure 6(c)).

3.1.3. Macrophyte Distribution. Macroalgal biomass was more abundant in the southern basin (Table 1), where it was found at most of the sites (Figure 7). In the northern and central part of the lagoon, some sites, mainly on the landward side, had no macroalgal coverage at all. C. nodosa and $Z$. marina were recorded in the southern basin and in a few sites in the central one (Figure 7), showing a progressive expansion of meadows [18]. In the northern basin seagrass coverage was negligible.

3.1.4. Statistical Analyses. The Kolmogorov-Smirnov tests highlighted non-normal distribution for salinity, $\mathrm{pH}$, oxygen saturation, and macrophyte biomass, for which values were log-transformed.

Correlations of $r_{s} \geq|0.26|$ were highly significant $(p<$ $0.001)$. Salinity was not found to be related to nutrient and carbon distribution but was positively correlated with temperature, $\mathrm{pH}$, and macrophyte biomass. Among benthic producers, seagrasses (but not macroalgae) were negatively correlated with fines and OP. Fines were also the main driver for 
TABLE 1: Abiotic and biotic data measured in Venice Lagoon and sub-basins in 2003 survey (mean \pm standard deviation (Std Dev), minimum (Min) and maximum (Max) values).

\begin{tabular}{|c|c|c|c|c|c|c|c|}
\hline & & & & Whole lagoon (W) & Northern basin $(\mathrm{N})$ & Central basin $(\mathrm{C})$ & Southern basin $(\mathrm{S})$ \\
\hline \multirow{2}{*}{ Depth } & \multirow{2}{*}{$D$} & \multirow{2}{*}{$\mathrm{cm}$} & Mean \pm Std Dev & $117 \pm 50.2$ & $82.6 \pm 25.7$ & $136 \pm 48.6$ & $109 \pm 49.7$ \\
\hline & & & $\operatorname{Min} \div \operatorname{Max}$ & $25.0 \div 270$ & $45.0 \div 130$ & $40.0 \div 270$ & $25.0 \div 205$ \\
\hline \multirow{2}{*}{ Temperature } & \multirow{2}{*}{$T$} & \multirow{2}{*}{${ }^{\circ} \mathrm{C}$} & Mean \pm Std Dev & $27.2 \pm 1.93$ & $28.3 \pm 1.09$ & $26.1 \pm 1.84$ & $28.0 \pm 1.61$ \\
\hline & & & $\operatorname{Min} \div \operatorname{Max}$ & $22.7 \div 33.2$ & $26.3 \div 30.2$ & $22.7 \div 33.2$ & $24.4 \div 30.9$ \\
\hline \multirow{2}{*}{$\mathrm{pH}$} & \multirow{2}{*}{$\mathrm{pH}$} & & Mean \pm Std Dev & $8.20 \pm 0.56$ & $9.10 \pm 0.14$ & $7.73 \pm 0.34$ & $8.39 \pm 0.35$ \\
\hline & & & $\operatorname{Min} \div \operatorname{Max}$ & $7.41 \div 9.35$ & $8.85 \div 9.35$ & $7.41 \div 9.20$ & $7.83 \div 9.25$ \\
\hline \multirow{2}{*}{ Salinity } & \multirow{2}{*}{$S$} & & Mean \pm Std Dev & $33.5 \pm 3.28$ & $36.6 \pm 4.28$ & $31.2 \pm 2.92$ & $34.8 \pm 1.58$ \\
\hline & & & Min $\div$ Max & $18.1 \div 43.1$ & $24.2 \div 43.1$ & $18.1 \div 35.6$ & $27.8 \div 37.2$ \\
\hline \multirow{2}{*}{ Secchi disk } & \multirow{2}{*}{ SD } & \multirow{2}{*}{$\%$} & Mean \pm Std Dev & $87.5 \pm 21.0$ & $86.7 \pm 19.5$ & $75.8 \pm 24.7$ & $98.1 \pm 9.15$ \\
\hline & & & Min $\div$ Max & $20.0 \div 100$ & $37.5 \div 100$ & $20.0 \div 100$ & $42.9 \div 100$ \\
\hline \multirow{2}{*}{ Oxygen saturation } & \multirow{2}{*}{ OS } & \multirow{2}{*}{$\%$} & Mean \pm Std Dev & $116 \pm 32.0$ & $133 \pm 36.6$ & $116 \pm 26.0$ & $112 \pm 34.5$ \\
\hline & & & $\operatorname{Min} \div \operatorname{Max}$ & $15.7 \div 239$ & $95.5 \div 239$ & $82.5 \div 224$ & $15.7 \div 208$ \\
\hline \multirow{2}{*}{ Sediment fine fraction } & \multirow{2}{*}{ SFF } & \multirow{2}{*}{$\%$} & Mean \pm Std Dev & $61.3 \pm 28.0$ & $88.7 \pm 11.6$ & $63.5 \pm 27.6$ & $52.6 \pm 26.7$ \\
\hline & & & $\operatorname{Min} \div \operatorname{Max}$ & $1.91 \div 99.3$ & $60.4 \div 99.3$ & $1.91 \div 98.6$ & $3.48 \div 98.0$ \\
\hline \multirow{2}{*}{ Sediment dry density } & \multirow{2}{*}{ SDD } & \multirow{2}{*}{$\mathrm{g} / \mathrm{cm}^{3}$} & Mean \pm Std Dev & $0.95 \pm 0.29$ & $0.80 \pm 0.19$ & $1.04 \pm 0.25$ & $0.91 \pm 0.32$ \\
\hline & & & $\operatorname{Min} \div \operatorname{Max}$ & $0.19 \div 1.47$ & $0.49 \div 1.24$ & $0.45 \div 1.47$ & $0.19 \div 1.44$ \\
\hline \multirow{2}{*}{ Macroalgal biomass } & \multirow{2}{*}{$\mathrm{Mb}$} & \multirow{2}{*}{$\mathrm{kg}$ fwt $/ \mathrm{m}^{2}$} & Mean \pm Std Dev & $0.41 \pm 0.89$ & $0.27 \pm 0.55$ & $0.18 \pm 0.42$ & $0.66 \pm 1.17$ \\
\hline & & & $\operatorname{Min} \div \operatorname{Max}$ & $0.01 \div 7.50$ & $0.01 \div 1.50$ & $0.01 \div 3.00$ & $0.01 \div 7.50$ \\
\hline \multirow{3}{*}{ Seagrass biomass } & \multirow{3}{*}{$\mathrm{Sb}$} & \multirow{3}{*}{$\mathrm{kg} \mathrm{fwt} / \mathrm{m}^{2}$} & Mean \pm Std Dev & $1.19 \pm 2.16$ & $\mathbf{0} \pm \mathbf{0}$ & $0.63 \pm 1.57$ & $1.99 \pm 2.57$ \\
\hline & & & $\operatorname{Min} \div \operatorname{Max}$ & $0 \div 7.30$ & $0 \div 0$ & $0 \div 5.40$ & $0 \div 7.30$ \\
\hline & & & Observations & 165 & 19 & 69 & 77 \\
\hline
\end{tabular}

nutrient distribution (being negatively correlated with TP and IP and positively correlated with OP and TN). TP and TC variations both depended almost entirely on changes in the inorganic fractions, Spearman's coefficients being 0.95 and 0.98 , respectively. Lastly, the distributions of OP and OC were positively correlated with TN.

Two axes explained $67.40 \%$ of cumulative variation in the RDA. Axis 1 (Figure 8) tends to isolate most of the southern basin sites from most of the central basin sites. According to the environmental data, axis 1 separates sites with higher OP content (on the right) from sites with more seagrasses and macroalgae and higher salinity, $\mathrm{pH}$, OS, and IP (on the left). Axis 2 points to a partition based mainly on IC, SDD, $\mathrm{TN}$, and fines (with Spearman rho values of $0.60,0.72,-0.75$, and -0.70 , resp.). Northern basin sites are mostly grouped in the lower part of the graph, being characterized by muddy sediments.

3.2. Changes in the Central Basin from 1987 to 2003. Sediment samples collected in 31 sites located in the central lagoon in 2003 were compared with samples taken from the same sites in 1987, 1993, and 1998. Mean salinity, fines, TC, IC, and TP did not change significantly during the study period (ANOVA per time $p>0.05$; Table 2), but the maps and the ANOVA per site $(p<0.001)$ showed important changes in spatial distribution, mainly that of fines (Figures 3(b), 3(c), and 3(d)), which decreased in landward areas. All other parameters displayed highly significant changes both on spatial and temporal scales (two-way ANOVA $p<0.001$; Table 2). Specifically, there was a decreasing trend of macroalgal biomass and consequently a reduction in $\mathrm{pH}$ and oxygen saturation (Table 2). Concerning sediment concentrations, the most important variations were observed for TN, OP, and OC (Figures 4(b), 4(c), 4(d), 4(e), 5(b), 5(c), 5(d), 5(e), 6(b), 6(c), 6(d), and 6(e); Table 2). The mean TN value in 2003 was roughly half that of 1987 and both the maximum and minimum values were 2.5 times lower than 1987. On a spatial scale, the central basin displayed almost homogeneous TN distribution, with most values $<1 \mathrm{mg} \mathrm{cm}^{-3}$ (Figures 4(b), 4(c), 4(d), and 4(e)). In previous years a more patchy distribution highlighted areas of urban discharge such as the city of Venice. TN reduction was progressive throughout the years (Table 2), whereas OP decreased mainly between 1987 and 1993, the period of macroalgal biomass decline (Table 2). On a spatial scale the most significant OP depletion was recorded south of Venice, with values uniformly below $50 \mu \mathrm{g} \mathrm{cm}^{-3}$ in 2003 (Figures 5(b), 5(c), 5(d), and 5(e)). OC fluctuations did not follow a univocal trend (Table 2), being highest in 1998 and lowest in 2003. In the latter case, the city of Venice divided the central basin into two areas: the northern one, characterized by values of $<5 \mathrm{mg} \mathrm{cm}^{-3}$, and the southern one with concentrations ranging between 5 and $10 \mathrm{mg} \mathrm{cm}^{-3}$ (Figures 6(b), 6(c), 6(d), and $6(\mathrm{e}))$.

\section{Discussion}

Pristine and unimpacted coastal ecosystems that could be used as benchmarks for assessing recovery of degraded areas 

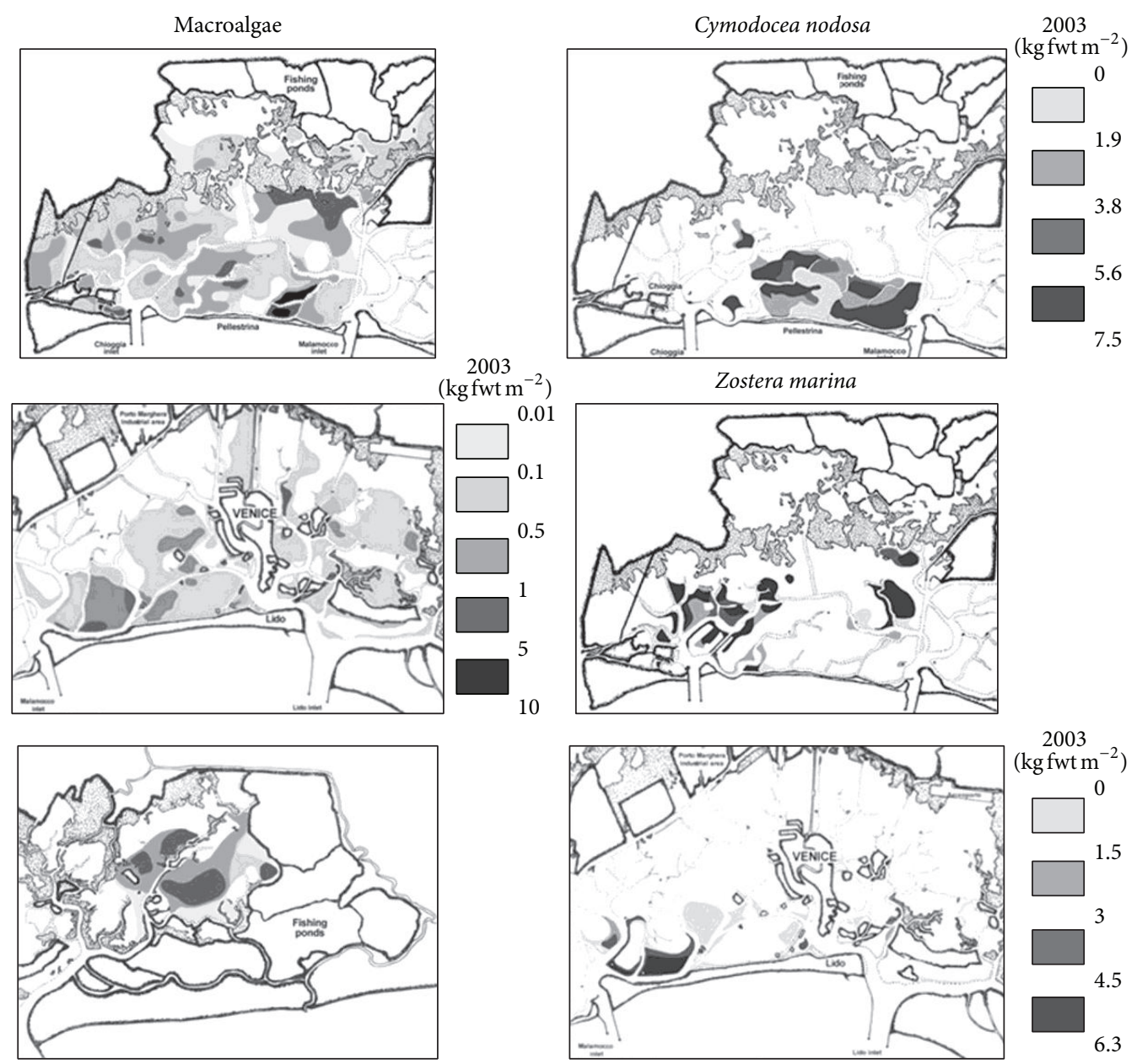

2003

$\left(\mathrm{kg} \mathrm{fwt} \mathrm{m}^{-2}\right)$

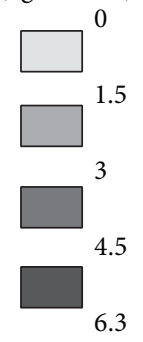

FIgURE 7: Macrophyte biomass distribution in 2003. Modified from [18].

have almost disappeared [7]. However, time series data [40] can make it possible to trace environmental evolution, showing how ecosystems change in relation to anthropogenic pressures and subsequent recovery measures. Although coastal lagoon environmental restoration seeks to reduce nutrient enrichment, it mainly entails morphological measures, with no action taken to reduce nutrient inputs $[9,10]$. Case studies show that such a strategy is not sufficient to restore ecosystem self-sustainability and that effective limits on anthropogenic discharges are necessary. This is confirmed by the case of Tampa Bay (Florida, USA), where the reduction of nutrient inputs enabled seagrass recolonization in about a decade [4]. Borja et al. [41] listed 50 subtidal and intertidal coastal ecosystems affected by different anthropogenic pressures (wastewater discharge, eutrophication, fish-farming and trawling, sewage sludge disposal, etc.) and indicated the time span for recovery after restoration or removal of pressures. Data on the recovery times of macroalgae and seagrasses are available for only 7 cases, of which only 2 involve areas affected by eutrophication [41].

In the present paper the ecological evolution of Venice Lagoon over a 16-year period was related both to measures to reduce nutrient inputs and anthropogenic impact and to natural changes such as the fall in macroalgal biomass mainly as a result of climate change [42].

In the late 1980s biogeochemical cycles were mostly driven by nuisance macroalgal blooms, with huge nutrient uptake and massive biomass decay. Management policies (wastewater treatment plants, banning of phosphate compounds from detergent formulation by the Decree of the President of the Italian Republic n. 250/1989, mechanical collection of macroalgal biomass) seeking to limit eutrophication and its effects were successful only after nuisance macroalgal proliferation was compromised by unfavourable weather conditions $[15,18]$. A significant fall in water column nutrient levels had already been seen by the 2000s [43, 44]. This paper highlights nutrient reductions in surface sediments, especially for TN, OP, and OC (Table 2; Figures 4(e), 5(e), and 6(e)). This strong decrease depended mainly on the elimination of huge biomass production and collapse cycles and on the start of intense clam harvesting in the mid-1990s. However, intense clam harvesting by heavy hydraulic and mechanical dredges also caused disruption of benthic habitats, persistent water turbidity, resuspension and redistribution of toxic contaminants (Figures 3(b) and 3(c)), and loss of fines (Table 2), further affecting primary production [45]. 
TABLE 2: Abiotic and biotic data measured in central part of Venice Lagoon in 1987, 1993, 1998, and 2003 surveys (mean \pm standard deviation (Std Dev), minimum (Min) and maximum (Max) values).

\begin{tabular}{|c|c|c|c|c|c|c|c|}
\hline & & & 1987 & 1993 & 1998 & 2003 & ANOVA \\
\hline \multirow{2}{*}{ Temperature* } & \multirow{2}{*}{${ }^{\circ} \mathrm{C}$} & Mean \pm Std Dev & $22.9 \pm 2.14$ & $25.7 \pm 1.70$ & $24.7 \pm 2.72$ & $25.7 \pm 1.33$ & \multirow{2}{*}{$<0.001$} \\
\hline & & $\operatorname{Min} \div \operatorname{Max}$ & $18.8 \div 27.8$ & $22.9 \div 29.6$ & $20.7 \div 29.7$ & $22.7 \div 29.7$ & \\
\hline \multirow{2}{*}{$\mathrm{pH}^{*}$} & & Mean \pm Std Dev & $8.86 \pm 0.38$ & $8.48 \pm 0.19$ & $8.02 \pm 0.13$ & $7.65 \pm 0.10$ & \multirow{2}{*}{$<0.001$} \\
\hline & & $\operatorname{Min} \div \operatorname{Max}$ & $8.18 \div 9.54$ & $8.21 \div 8.80$ & $7.65 \div 8.27$ & $7.41 \div 7.85$ & \\
\hline \multirow{2}{*}{ Salinity } & & Mean \pm Std Dev & $30.7 \pm 1.72$ & $31.4 \pm 2.1$ & $29.6 \pm 3.16$ & $30.9 \pm 3.44$ & \multirow{2}{*}{0.08} \\
\hline & & $\operatorname{Min} \div \operatorname{Max}$ & $25.5 \div 33.6$ & $24.7 \div 34.8$ & $22.2 \div 34.9$ & $18.0 \div 35.4$ & \\
\hline \multirow{2}{*}{ Oxygen saturation* } & \multirow{2}{*}{$\%$} & Mean \pm Std Dev & $282 \pm 73.4$ & $134 \pm 29.0$ & $116 \pm 27.5$ & $115 \pm 22.3$ & \multirow{2}{*}{$<0.001$} \\
\hline & & $\operatorname{Min} \div \operatorname{Max}$ & $159 \div 392$ & $88.0 \div 214$ & $70.0 \div 202$ & $82.5 \div 181$ & \\
\hline \multirow{2}{*}{ Sediment fine fraction } & \multirow{2}{*}{$\%$} & Mean \pm Std Dev & $70.5 \pm 27.1$ & & $60.4 \pm 29.1$ & $64.3 \pm 29.8$ & \multirow{2}{*}{0.12} \\
\hline & & $\operatorname{Min} \div \operatorname{Max}$ & $12.6 \div 98.7$ & & $11.1 \div 95.8$ & $5.69 \div 98.2$ & \\
\hline \multirow{2}{*}{ Macroalgal biomass* } & \multirow{2}{*}{$\mathrm{kg}$ fwt $/ \mathrm{m}^{2}$} & Mean \pm Std Dev & $5.86 \pm 6.05$ & $0.51 \pm 1.50$ & $0.20 \pm 0.99$ & $0.08 \pm 0.18$ & \multirow{2}{*}{$<0.001$} \\
\hline & & $\operatorname{Min} \div \operatorname{Max}$ & $0 \div 25.0$ & $0 \div 7.50$ & $0 \div 5.50$ & $0 \div 0.80$ & \\
\hline \multirow{2}{*}{ Total nitrogen ${ }^{*}$} & \multirow{2}{*}{$\mathrm{mg} / \mathrm{cm}^{3}$} & Mean \pm Std Dev & $1.19 \pm 0.62$ & $1.13 \pm 0.50$ & $0.86 \pm 0.38$ & $0.70 \pm 0.27$ & \multirow{2}{*}{$<0.001$} \\
\hline & & $\operatorname{Min} \div \operatorname{Max}$ & $0.22 \div 2.98$ & $0.33 \div 2.62$ & $0.13 \div 1.37$ & $0.09 \div 1.15$ & \\
\hline \multirow{2}{*}{ Inorganic phosphorus* } & \multirow{2}{*}{$\mu \mathrm{g} / \mathrm{cm}^{3}$} & Mean \pm Std Dev & $282 \pm 73.8$ & $295 \pm 73.8$ & $320 \pm 60.7$ & $332 \pm 83.2$ & \multirow{2}{*}{0.001} \\
\hline & & $\operatorname{Min} \div \operatorname{Max}$ & $146 \div 474$ & $141 \div 423$ & $215 \div 466$ & $216 \div 660$ & \\
\hline \multirow{2}{*}{ Organic phosphorus* } & \multirow{2}{*}{$\mu \mathrm{g} / \mathrm{cm}^{3}$} & Mean \pm Std Dev & $105 \pm 43.3$ & $65.0 \pm 27.4$ & $66.5 \pm 27.0$ & $53.2 \pm 28.4$ & \multirow{2}{*}{$<0.001$} \\
\hline & & $\operatorname{Min} \div \operatorname{Max}$ & $49.0 \div 246$ & $27.0 \div 124$ & $15.3 \div 117$ & $3.02 \div 114$ & \\
\hline \multirow{2}{*}{ Total phosphorus } & \multirow{2}{*}{$\mu \mathrm{g} / \mathrm{cm}^{3}$} & Mean \pm Std Dev & $387 \pm 101$ & $360 \pm 82.6$ & $386 \pm 54.9$ & $385 \pm 79.7$ & \multirow{2}{*}{0.27} \\
\hline & & $\operatorname{Min} \div \operatorname{Max}$ & $227 \div 720$ & $184 \div 511$ & $302 \div 534$ & $295 \div 665$ & \\
\hline \multirow{2}{*}{ Inorganic carbon } & \multirow{2}{*}{$\mathrm{mg} / \mathrm{cm}^{3}$} & Mean \pm Std Dev & $66.4 \pm 24.8$ & $67.6 \pm 27.0$ & $68.0 \pm 21.5$ & $72.3 \pm 22.7$ & \multirow{2}{*}{0.08} \\
\hline & & $\operatorname{Min} \div \operatorname{Max}$ & $25.3 \div 117$ & $22.0 \div 120$ & $38.4 \div 121$ & $28.1 \div 123$ & \\
\hline Oroanic carbon* & $\mathrm{mo} / \mathrm{cm}^{3}$ & Mean \pm Std Dev & $8.85 \pm 3.45$ & $6.68 \pm 3.30$ & $10.7 \pm 3.57$ & $5.62 \pm 2.64$ & \\
\hline & & $\operatorname{Min} \div \operatorname{Max}$ & $2.72 \div 16.7$ & $1.91 \div 14.2$ & $4.30 \div 18.5$ & $0.92 \div 12.7$ & $<0.001$ \\
\hline Total carbon & $\mathrm{mo} / \mathrm{sm}^{3}$ & Mean \pm Std Dev & $75.2 \pm 23.9$ & $74.3 \pm 25.9$ & $78.7 \pm 19.9$ & $77.9 \pm 22.0$ & 023 \\
\hline & & $\operatorname{Min} \div \operatorname{Max}$ & $33.8 \div 124$ & $25.6 \div 123$ & $51.3 \div 127$ & $33.6 \div 124$ & \\
\hline & & Observations & 31 & 31 & 31 & 31 & \\
\hline
\end{tabular}

* Significant temporal fluctuations (ANOVA test, $p<0.05$ ).

The loss of TN in the top layer of sediments in the period when clam density was high and the intense harvesting had not yet started may be also explained by sediment bioperturbation due to clam burrowing, which plays a significant role in the nitrogen cycle, favouring the release of ammonium and orthophosphates and the intensification of denitrification processes [46, 47]. In the central basin, the most severely affected by clam harvesting, industrial and urban discharges, and naval traffic, TN distribution was $<1 \mathrm{mg} \mathrm{cm}^{-3}$ almost everywhere. In contrast, areas less affected by clam harvesting, such as the southern lagoon, maintained higher TN concentrations, confirming the hypothesis of significant loss driven by sediment perturbation. In fact, pore water released by sediment perturbation contains ammonium and orthophosphates at concentrations 2-3 orders of magnitude higher than the water column [48].

Likewise, the disappearance of high macroalgal biomass and the sediment washing arising from clam catching strongly reduced OP, whereas IP remained almost the same (Table 2). The depletion of phosphorus in the water column [43] has made it the main limiting factor for phytoplankton and macroalgal growth. Although phosphorus concentrations have also fallen in surface sediments, the overall effect has been to favour the spread of seagrasses, as observed in 2003 and subsequent years, since these organisms can still tap into sedimentary phosphorus via their root-rhizome system whereas macroalgal biomass decreases. Seagrasses, especially C. nodosa and Z. marina, are now the lagoon's main producers [18], suggesting rapid restoration of good/high ecological conditions. Even though the most confined areas of the lagoon have not yet been recolonized by seagrasses, because of the absence of seeds or rhizomes, these results show that the fall in nutrient concentrations has significantly favoured progressive environmental recovery. In the absence of further anthropogenic impacts, this is likely to continue over the next few years (Figure 1). In other coastal ecosystems, nutrient load reduction has been seen to lead to the recovery of seagrass meadows: in Tampa Bay (Florida) and Mondego Bay (Portugal), where seagrasses had almost disappeared, they now cover areas of $27 \mathrm{~km}^{2}$ and $1.6 \mathrm{~km}^{2}$, respectively [49].

Any comparison with other coastal transitional ecosystems must bear in mind that chemical values in the top layer of sediments may be influenced by several factors, including morphology, hydrodynamism, and seasonal fluctuations. However, in Óbidos Lagoon (Portugal), for example, a study showed that nutrient concentrations depended on distance 


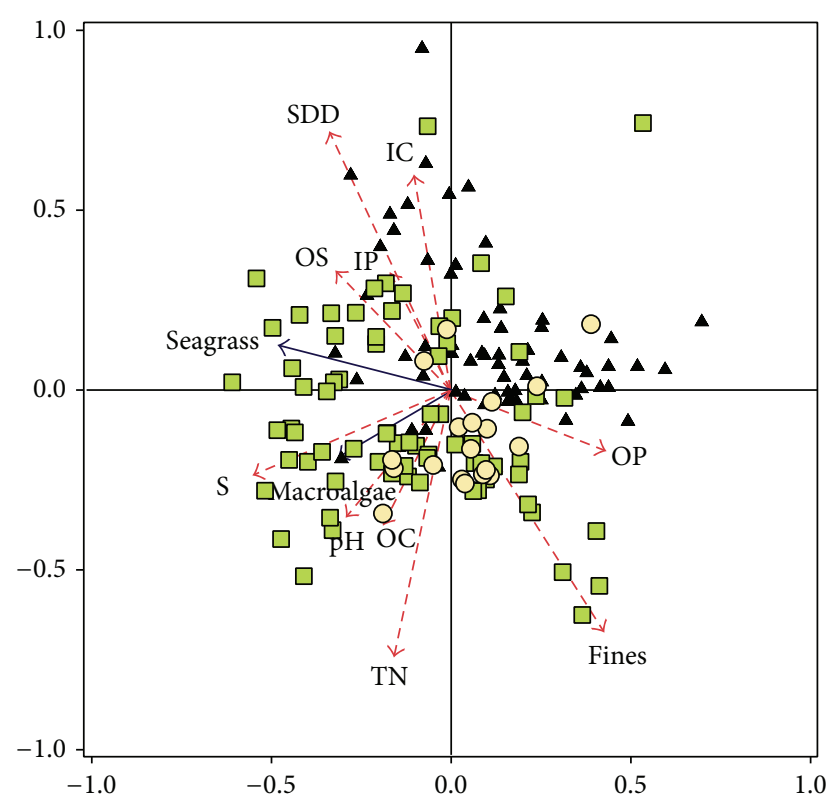

FIgURE 8: Redundancy analysis (RDA) for dataset including 165 observations in whole lagoon, 2 biotic factors (macroalgae and seagrass), and 9 environmental variables: $S=$ salinity, $\mathrm{pH}, \mathrm{OS}=$ oxygen saturation, fines $=$ sediment fine fraction, $\mathrm{TN}=$ total nitrogen, $\mathrm{IP}=$ inorganic phosphorus, OP = organic phosphorus, IC = inorganic carbon, and $\mathrm{OC}=$ organic carbon. Black triangles represent central basin samples; green squares represent southern basin samples; yellow circles represent northern basin samples. First and second axes explain $50.7 \%$ and $16.7 \%$ of variation, respectively.

from the Cal River mouth: TN ranged between 0.09 and $2.5 \mathrm{mg} \mathrm{g}^{-1}$ and TP ranged between 14 and $855 \mu \mathrm{g} \mathrm{g}^{-1}$, being lowest on the seaward side [50]. Similarly, OC ranged from 0.16 to $29.0 \mathrm{mg} \mathrm{g}^{-1}$. In Corunna Lake (Australia) average TP and $\mathrm{TN}$ values ranged between 380 and $800 \mu \mathrm{gg}^{-1}$ and between 3.5 and $5.0 \mathrm{mg} \mathrm{g}^{-1}$, respectively [51]. The latter values are, on average, 3-4 times higher than the 2003 values for Venice (Figure 4) but are similar to the concentrations found in other Adriatic transitional systems such as the lagoons of Marano-Grado (TN: ca. $4.5 \mathrm{mgg}^{-1}$, [52]) and the Po Delta (TN: ca. $1.48 \mathrm{mg} \mathrm{g}^{-1},[53]$ ).

\section{Conclusions}

Venice Lagoon is an example of a transitional ecosystem in continuous evolution due to human intervention aimed not only at safeguarding but also at exploiting its resources. The reduction of macroalgal biomasses caused by climate change and other synergic factors [42], together with measures to reduce nutrient inputs [16], and the effect of sediment disturbance by anthropogenic activities such as clam harvesting and morphological intervention caused a significant decrease not only in OP but also in TN and OC in the top layer of sediments, with redistribution of fine sediments and disappearance of hot spot areas. As a result, the lagoon is still subject to significant anthropogenic pressures but the reduction in trophic status has allowed natural recolonization by seagrasses, so that many areas are moving towards a restoration of pristine conditions [18]. Lastly, the results of this paper represent a benchmark for the future, making it possible to highlight the effects of the ongoing regulation of water exchange at the lagoon inlets (including the use of mobile gates envisaged by the MoSE project), whose purpose is to prevent the frequent high water events affecting Venice and its lagoon.

\section{Conflict of Interests}

The authors declare that there is no conflict of interests regarding the publication of this paper.

\section{Acknowledgment}

The authors wish to thank Mr. George Metcalf for the English editing.

\section{References}

[1] E. E. Prepas and T. Charette, "Worldwide eutrophication of water bodies: causes, concerns, controls," in Treatise on Geochemistry, B. Sherwood Lollar, Ed., pp. 311-331, Elsevier, 2003.

[2] V. N. de Jonge, M. Elliott, and E. Orive, "Causes, historical development, effects and future challenges of a common environmental problem: eutrophication," Hydrobiologia, vol. 475476, pp. 1-19, 2002.

[3] V. H. Smith, "Eutrophication of freshwater and coastal marine ecosystems: a global problem," Environmental Science and Pollution Research, vol. 10, no. 2, pp. 126-139, 2003.

[4] J. E. Cloern, "Our evolving conceptual model of the coastal eutrophication problem," Marine Ecology Progress Series, vol. 210, pp. 223-253, 2001.

[5] K. J. McGlathery, K. Sundbäck, and I. C. Anderson, "Eutrophication in shallow coastal bays and lagoons: the role of plants in the coastal filter," Marine Ecology Progress Series, vol. 348, pp. 1-18, 2007.

[6] P. Viaroli, M. Bartoli, G. Giordani, M. Naldi, S. Orfanidis, and J. M. Zaldivar, "Community shifts, alternative stable states, biogeochemical controls and feedbacks in eutrophic coastal lagoons: a brief overview," Aquatic Conservation: Marine and Freshwater Ecosystems, vol. 18, no. 1, pp. S105-S117, 2008.

[7] L. Airoldi and M. W. Beck, "Loss, status and trends for coastal marine habitats of Europe," in Oceanography and Marine Biology: An Annual Review, R. N. Gibson, R. J. A. Atkinson, and J. D. M. Gordon, Eds., vol. 45, pp. 345-405, Taylor \& Francis, London, UK, 2007.

[8] Ramsar Convention Secretariat, The Ramsar Convention Manual: a guide to the Convention on Wetlands ( Ramsar, Iran, 1971), Ramsar Convention Secretariat, Gland, Switzerland, 6th edition, 2013.

[9] A. Camacho, R. Peinado, A. C. Santamans, and A. Picazo, "Functional ecological patterns and the effect of anthropogenic disturbances on a recently restored Mediterranean coastal lagoon. Needs for a sustainable restoration," Estuarine, Coastal and Shelf Science, vol. 114, pp. 105-117, 2012.

[10] S. Wijnhoven, V. Escaravage, E. Daemen, and H. Hummel, "The decline and restoration of a coastal Lagoon (Lake Veere ) in the Dutch Delta," Estuaries and Coasts, vol. 33, no. 6, pp. 1261-1278, 2010. 
[11] P. Tett, R. Gowen, D. Mills et al., "Defining and detecting undesirable disturbance in the context of marine eutrophication," Marine Pollution Bulletin, vol. 55, no. 1-6, pp. 282-297, 2007.

[12] A. Sfriso, C. Facca, and P. F. Ghetti, "Validation of the Macrophyte Quality Index (MaQI) set up to assess the ecological status of Italian marine transitional environments," Hydrobiologia, vol. 617, no. 1, pp. 117-141, 2009.

[13] C. Solidoro, V. F. Bandelj, E. Bernardi Aubry et al., "Responses of the Venice Lagoon eco system to natural and anthropogenic pressures over the last 50 years," in Costal Lagoons, Critical Habitats of Environmental Changes, M. J. Kennish and H. W. Paerl, Eds., pp. 483-511, CRC Press, Boca Raton, Fla, USA, 2010.

[14] A. Marcomini, A. Sfriso, B. Pavoni, and A. A. Orio, "Eutrophication of the lagoon of Venice: nutrient loads and exchanges," in Eutrophic Shallow Estuaries and Lagoons, A. J. McComb, Ed., pp. 59-80, CRC Press, Boca Raton, Fla, USA, 1995.

[15] A. Sfriso, C. Facca, and P. F. Ghetti, "Temporal and spatial changes of macroalgae and phytoplankton in a Mediterranean coastal area: the Venice lagoon as a case study," Marine Environmental Research, vol. 56, no. 5, pp. 617-636, 2003.

[16] R. Pastres, C. Solidoro, S. Ciavatta, A. Petrizzo, and G. Cossarini, "Long-term changes of inorganic nutrients in the Lagoon of Venice (Italy)," Journal of Marine Systems, vol. 51, no. 1-4, pp. 179-189, 2004.

[17] A. Sfriso and A. Marcomini, "Chapter 15: Italy-The lagoon of Venice," in Marine Benthic Vegetation, Ecological Studies, W. Schramm and P. N. Nienhuis, Eds., vol. 123, pp. 339-368, Springer, Berlin, Germany, 1996.

[18] A. Sfriso and C. Facca, "Distribution and production of macrophytes and phytoplankton in the lagoon of Venice: comparison of actual and past situation," Hydrobiologia, vol. 577, no. 1, pp. 71-85, 2007.

[19] F. Pranovi, G. Franceschini, M. Casale, M. Zucchetta, P. Torricelli, and O. Giovanardi, "An ecological imbalance induced by a non-native species: the Manila clam in the Venice Lagoon," Biological Invasions, vol. 8, no. 4, pp. 595-609, 2006.

[20] G. Orel, V. Boatto, A. Sfriso, and M. Pellizzato, "Piano per la gestione delle risorse alieutiche delle lagune della Provincia di Venezia," in Provincia di Venezia, Sannioprint, Benevento, Italy, 2000.

[21] A. Sfriso, C. Facca, S. Ceoldo, G. Pessa, and P. Campostrini, "Sedimentation rates, erosive processes, grain-size and sediment density changes in the lagoon of venice," in Scientific Research and Safeguarding of Venice, P. Campostrini, Ed., vol. 3, pp. 203-213, Corila, Venice, Italy, 2005.

[22] E. Molinaroli, S. Guerzoni, A. Sarretta, M. Masiol, and M. Pistolato, "Thirty-year changes (1970 to 2000) in bathymetry and sediment texture recorded in the Lagoon of Venice subbasins, Italy," Marine Geology, vol. 258, no. 1-4, pp. 115-125, 2009.

[23] G. Badino, F. Bona, A. Maffiotti, O. Giovanardi, and F. Pranovi, "Impact of mechanical clam harvesting on a benthic habitat: evaluation by means of sediment profile imaging," Aquatic Conservation: Marine and Freshwater Ecosystems, vol. 14, no. 1, pp. S59-S67, 2004.

[24] A. Sfriso, C. Facca, S. Ceoldo, S. Silvestri, and P. F. Ghetti, "Role of macroalgal biomass and clam fishing on spatial and temporal changes in $\mathrm{N}$ and $\mathrm{P}$ sedimentary pools in the central part of the Venice lagoon," Oceanologica Acta, vol. 26, no. 1, pp. 3-13, 2003.

[25] M. Dalla Valle, A. Marcomini, A. Sfriso, A. J. Sweetman, and K. C. Jones, "Estimation of PCDD/F distribution and fluxes in the
Venice Lagoon, Italy: combining measurement and modelling approaches," Chemosphere, vol. 51, no. 7, pp. 603-616, 2003.

[26] B. Pavoni, M. Caliceti, L. Sperni, and A. Sfriso, "Organic micropollutants (PAHs, PCBs, pesticides) in seaweeds of the lagoon of Venice," Oceanologica Acta, vol. 26, no. 5-6, pp. 585596, 2003.

[27] P. Torricelli, V. Boatto, P. Franzoi, M. Pellizzato, and S. Silvestri, Managment Plan for the Alieutic Sources in the Lagoon of the Venice Territory, Provincia di Venezia, Assessorato Caccia, Pesca e Polizia Provinciale, Venezia, Italy, 2009, (Italian).

[28] P. Pirazzoli, "Dati storici sul medio mare a Venezia," Atti della Accademia delle Scienze dell'Istituto di Bologna, vol. 13, no. 1, pp. 125-148, 1974.

[29] M. Oxner, The Determination of Chlorinity by the Knudsen Method and Hydrographical Tables, G.M. Manufacturing, New York, NY, USA, 1962.

[30] A. J. Bale and A. J. Kenny, "Sediment analysis and seabed characterization," in Methods for the Study of Marine Benthos, A. Eleftheriou and A. Mcintyre, Eds., pp. 43-81, Blackwell Science, Oxford, UK, 2005.

[31] B. W. Flemming, "A revised textural classification of gravel-free muddy sediments on the basis of ternary diagrams," Continental Shelf Research, vol. 20, no. 10-11, pp. 1125-1137, 2000.

[32] K. I. Aspila, H. Agemian, and A. S. Y. Chau, "A semi-automated method for the determination of inorganic, organic and total phosphate in sediments," The Analyst, vol. 101, no. 1200, pp. 187197, 1976.

[33] J. D. Strickland and T. R. Parsons, A Practical Handbook of Seawater Analysis, Fisheries Research Board of Canada, Ottawa, Canada, 2nd edition, 1984.

[34] E. Kristensen and F. Ø. Andersen, "Determination of organic carbon in marine sediments: a comparison of two CHNanalyzer methods," Journal of Experimental Marine Biology and Ecology, vol. 109, no. 1, pp. 15-23, 1987.

[35] P. N. Froelich, "Analysis of organic carbon in marine sediments," Limnology and Oceanography, vol. 25, no. 3, pp. 564-572, 1980.

[36] A. Sfriso and P. Francesco Ghetti, "Seasonal variation in biomass, morphometric parameters and production of seagrasses in the lagoon of Venice," Aquatic Botany, vol. 61, no. 3, pp. 207-223, 1998.

[37] A. Sfriso, C. Facca, and S. Ceoldo, "Growth and production of Cymodocea nodosa (Ucria) Ascherson in the Venice lagoon," in Scientific Research and Safeguarding of Venice Volume II, P. Campostrini, Ed., pp. 229-236, CORILA, Venice, Italy, 2004.

[38] A. Sfriso, C. Facca, and S. Ceoldo, "Growth and net production of the seagrass Nanozostera noltii (Hornemann) Tomlinson et Posluzny in Venice lagoon," in Scientific Research and Safeguarding of Venice, P. Campostrini, Ed., vol. 6, pp. 281-291, CORILA, Venice, Italy, 2008.

[39] G. Umgiesser, A. Albani, C. L. Amos et al., "Hydrodynamics and morphology. Corila 3.2.", in Scientific Research and Safeguarding of Venice, P. Campostrini, Ed., vol. 3, pp. 111-130, CORILA, Venice, Italy, 2005.

[40] A. Pugnetti, F. Acri, F. Bernardi Aubry et al., "The Italian longterm ecosystem research (LTER-Italy) network: results, opportunities, and challenges for coastal transitional ecosystems," Transitional Waters Bulletin, vol. 7, no. 1, pp. 43-63, 2013.

[41] Á. Borja, D. M. Dauer, M. Elliott, and C. A. Simenstad, "Medium-and Long-term recovery of estuarine and coastal ecosystems: patterns, rates and restoration effectiveness," Estuaries and Coasts, vol. 33, no. 6, pp. 1249-1260, 2010. 
[42] A. Sfriso and A. Marcomini, "Decline of Ulva growth in the lagoon of Venice," Bioresource Technology, vol. 58, no. 3, pp. 299307, 1996.

[43] C. Facca, N. Pellegrino, S. Ceoldo, M. Tibaldo, and A. Sfriso, "Trophic conditions in the waters of the Venice Lagoon (Northern Adriatic Sea, Italy)," The Open Oceanography Journal, vol. 5, no. 1, pp. 1-13, 2011.

[44] F. Bernardi Aubry, F. Acri, F. Bianchi, and A. Pugnetti, "Looking for patterns in the phytoplankton community of the Mediterranean microtidal Venice lagoon: evidence from ten years of observations," Scientia Marina, vol. 77, no. 1, pp. 47-60, 2013.

[45] C. Facca, A. Sfriso, and G. Socal, "Changes in abundance and composition of phytoplankton and microphytobenthos due to increased sediment fluxes in the Venice lagoon, Italy," Estuarine, Coastal and Shelf Science, vol. 54, no. 5, pp. 773-792, 2002.

[46] A. Sfriso and A. Marcomini, "Gross primary production and nutrient behaviour in a shallow coastal environment," Bioresource Technology, vol. 47, no. 1, pp. 59-66, 1994.

[47] J. M. Svensson, G. M. Carrer, and M. Bocci, "Nitrogen cycling in sediments of the Lagoon of Venice, Italy," Marine Ecology Progress Series, vol. 199, pp. 1-11, 2000.

[48] R. Donazzolo, D. Degobbis, A. Sfriso, B. Pavoni, and A. A. Orio, "Influence of Venice Lagoon macrofauna on nutrient exchange at the sediment-water interface," Science of the Total Environment, vol. 86, no. 3, pp. 223-238, 1989.

[49] M. Waycotta, C. M. Duarte, T. J. B. Carruthers et al., "Accelerating loss of seagrasses across the globe threatens coastal ecosystems," Proceedings of the National Academy of Sciences of the United States of America, vol. 106, no. 30, pp. 12377-12381, 2009.

[50] P. Pereira, H. De Pablo, C. Vale, F. Rosa-Santos, and R. Cesário, "Metal and nutrient dynamics in a eutrophic coastal lagoon (Óbidos, Portugal): the importance of observations at different time scales," Environmental Monitoring and Assessment, vol. 158, no. 1-4, pp. 405-418, 2009.

[51] D. R. Spooner and W. Maher, "Benthic sediment composition and nutrient cycling in an intermittently closed and open Lake Lagoon," Journal of Marine Systems, vol. 75, no. 1-2, pp. 33-45, 2009.

[52] S. Covelli, A. Emili, A. Acquavita, N. Koron, and J. Faganeli, "Benthic biogeochemical cycling of mercury in two contaminated northern Adriatic coastal lagoons," Continental Shelf Research, vol. 31, no. 16, pp. 1777-1789, 2011.

[53] A. Sfriso, C. D. Facca, D. Bon, and A. Buosi, Flora and Vegetation of Potransitional System, Environmental Parameters and Ecological State, 43rd Italian Society of Marine Biology (SIBM), Salerno, Italy, 2012, (Italian). 

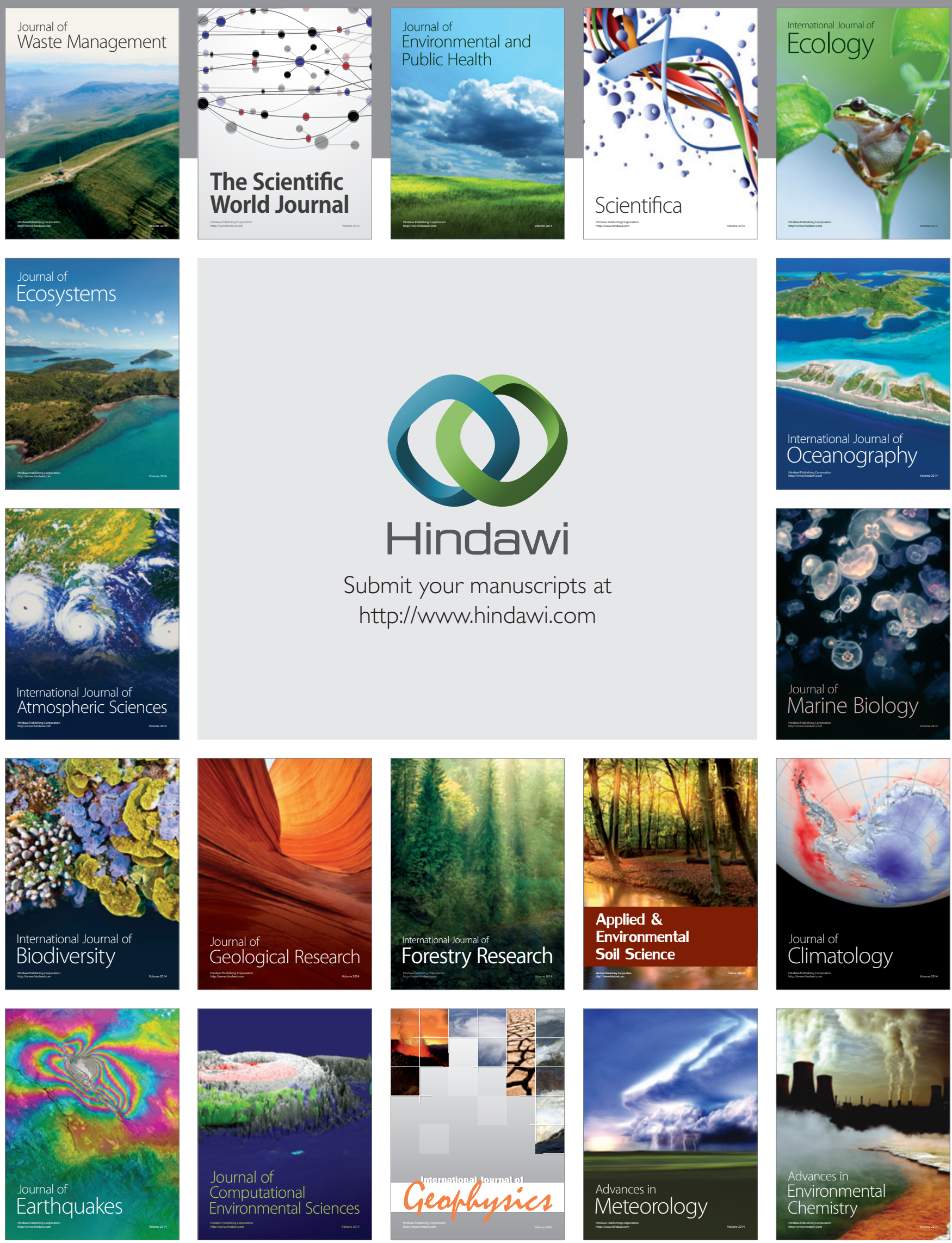